\begin{tabular}{|c|c|}
\hline ב & $\begin{array}{c}\text { International Journal of Current Research } \\
\text { and Academic Review }\end{array}$ \\
\hline $\begin{array}{l}\text { XCELENT } \\
\text { UBLISHERS }\end{array}$ & $\begin{array}{c}\text { ISSN: 2347-3215 (Online) } \because, ; \text { Volume 5:,; Number } 7 \text { (July-2017) } \\
\text { Journal homepage: http://www.ijcrar.com }\end{array}$ \\
\hline
\end{tabular}

doi: https://doi.org/10.20546/ijcrar.2017.507.15

\title{
Salivary Indicators for a Healthy Mouth: An In Vivo Study
}

\author{
N. Sunil Raj ${ }^{1}$, E. Umadevi ${ }^{2^{*}}$ and Sapna Konde ${ }^{3}$
}

${ }^{I}$ Department of Pedodontics and Preventive Dentistry, Bangalore Institute of Dental Sciences and Hospital and Postgraduate Research Centre, Karnataka, India

${ }^{2}$ No. 5/3, Hosur Main Road, Lakkasandra, adjacent to NIMHANS Convention Centre, Bengaluru, Karnataka 560027, India

${ }^{3}$ A.E.C.S Maaruti College of Dental Sciences and Research Centre No 108, BTM 6th Stage, 1st Phase, Hulimavu

Tank Bund Road, Off Bannerghatta Road, Bangalore 560076, Karnataka, India

*Corresponding author

\begin{abstract}
The study aimed to assess salivary properties like salivary $\mathrm{pH}$, buffering capacity and S.mutans count before and after restoration of carious lesions of primary teeth in children aged 6-12 years using three different restorative materials i.e. GIC, SS crown and composite, and divided into three groups of ten each and restored with the above materials respectively. $5 \mathrm{ml}$ of stimulated saliva was collected after thorough oral prophylaxis, $\mathrm{pH}$ was recorded using $\mathrm{pH}$ strips and buffering capacity by salivary buffering capacity test and S.mutans count was done by inoculating $1 \mathrm{ml}$ of saliva in MSB agar plate and counted after 3 days. The second and the third samples were collected on fifteenth and thirtieth day of restorations and assessed for the same. The analysed results showed a statistically significant increase in both salivary $\mathrm{pH}$ and buffering capacity and a decrease in S.mutans count in all the three groups when compared to the baseline data. No significant difference was seen between the groups. Hence, concluded that restoration of the tooth itself improves the salivary properties like salivary $\mathrm{pH}$ and buffering capacity and decreases the S.mutans count, irrespective of the materials used.
\end{abstract}

\section{Article Info}

Accepted: 02 July 2017

Available Online: 20 July 2017

\begin{tabular}{l} 
Keywords \\
\hline S.mutans Count, \\
pH, \\
Buffering capacity
\end{tabular}

\section{Introduction}

Dental caries is one of the most common human diseases, with a high prevalence in the early mixed dentition worldwide (Schipper, 2007; Smith, 2013; Ng MW a, b., 2014, 2012; Ai JY., 2012).

It results from an imbalance between multiple risk factors and protective factors in addition to interplay of three principles factors: host, microflora and substrate over the time. Although not directly involved, but past caries experience, social and behavioural factors can also aid in caries risk identification.

The flow of saliva, its buffer capacity and presence of fluoride play an important role in caries prevention (Sonbul, 2010). Stimulation of saliva results in a flushing effect that clears oral debris and noxious agents, dilutes and eliminates sugars and other substances, increases buffer capacity and balances demineralization/remineralization and antimicrobial activity (Anderson 2003). 
Saliva is a clinically informative, biological fluid that is useful for novel approaches to prognosis, laboratory or clinical diagnosis, and monitoring and management of patients with both oral and systemic diseases.

It is easily collected and stored and ideal for early detection of disease as it contains specific soluble biological markers (Stookey, 2008).

Salivary diagnostics has evolved into a sophisticated science, and serves as a subset of the larger field of molecular diagnostics, now recognized as a central player in a wide variety of biomedical basic and clinical areas (Stookey, 2008).

Carious surfaces alter conditions in oral cavity by increasing bacterial adherence, favouring plaque retention, decreasing carbohydrate clearance, and increasing acid production (Malamud et al., 2011).

Glass ionomer cement have the ability to neutralize the salivary acid by buffering the lactic acid via the release of chemical ions and also has an antibacterial effect (Mayanagi et al., 2011).

The antibacterial effects of composites for filling are mainly relevant to inhibition of plaque accumulation on the surface of the materials and tooth around the restoration (Subramanyam et al., 2016).

The systematic removal of all carious lesions and a thorough prophylaxis are sometimes considered to be effective methods for bringing the disease under control (Mayanagi et al., 2011; Subramanyam et al., 2016; I. Nedeljkovic et al., 2016).

However, there is little clinical or experimental evidence to support this concept (I. Nedeljkovic et al., 2016; Massler., 1969; Winter et al., 1973).

Hence our study evaluates and compares the efficacy of restorative materials like glass ionomer cement, composites and stainless-steel crowns on the salivary $\mathrm{pH}$, buffer capacity and S.mutans count.

\section{Materials and Methods}

The study was conducted on thirty children aged between 6-10 years, who visited the Department of Pedodontics \& preventive Dentistry, AECS Maaruti College of Dental Sciences \& Research Centre, Bangalore.

\section{Inclusion criteria}

1. Caries active children with at least two to three decayed teeth

2. Children with prior consent

\section{Exclusion criteria}

1. Medically compromised children.

2. Non-restorable tooth surfaces

The children were divided into three groups of ten each. Group I - restored with GIC, group II - restored with SSC (Stainless steel crowns) and group III - composite restorations $5 \mathrm{ml}$ of stimulated saliva was collected after thorough oral prophylaxis. The $\mathrm{pH}$ of the saliva was recorded using $\mathrm{pH}$ strips. About $1 \mathrm{ml}$ of saliva was inoculated into Mitis -Salivaris- Bacitracin (MSB) agar plate using a micropipette and inoculation loops. The buffering capacity was tested using salivary buffering capacity test.

Caries was excavated with spoon excavator and cavity preparation done using high speed airotor hand piece and no. 4 round bur followed by restoration with respective restorative material. Saliva samples were collected after 15 days and thirty days of the restoration and assessed for the same. The data obtained were tabulated and subjected to statistical analysis using One Way ANOVA test and inter group comparison was made using Tukeys multiple posthoc procedures.

\section{Results and Discussion}

The $\mathrm{pH}$ of the saliva increased after 15 days and 30 days of restoration in all the three groups which were statistically significant. In group I, $\mathrm{pH}$ improved from 6 (baseline) to 7.9, group II from 6.05 to 7.85 and in group III from 6.4 to 7.65 after 30 days. However, the difference between the groups was not statistically significant.

Table 2 represents the buffering capacity of saliva. There is significant improvement in the buffering capacity on the 15 th and $30^{\text {th }}$ day after restoration as compared to the baseline sample. The buffer capacity of group I showed a mean increase of $1.2+0.48$ after 30 day, group II \& III showed an increase of $1.9+0.39 \& 1.9+0.77$ respectively after 30 days. There was no statistically significant difference seen between the groups on the $15^{\text {th }}$ day of restoration, but showed statistically significant difference between group I \& II and group I 
$\&$ III on the $30^{\text {th }}$ day where GIC showedgreater increase in the buffer capacity.

Table 3 shows statistically significant reduction in the S.mutanscount at both $15^{\text {th }}$ and $30^{\text {th }}$ day interval. In group I the S.mutans count had reduced by $3.42+0.7730$ days after restoration. In group II the reduction was $3.55+$ 1.21 and in group III, the reduction was $3.93+0.93$. The difference between the groups at different time interval was not statistically significant.

Unstimulated saliva is essential for the health and wellbeing of the oral cavity and also bestows a strong protective effect to the oral cavity, against dental caries (Doyle, 1973; Amerongen et al., 2004).

The functions of saliva include lubricating the oral tissues, protecting the oral soft tissues from abrasion during mastication, facilitating the digestion of carbohydrates, antibacterial activity against foreign microorganisms, flushing the oral cavity to remove food particles and debris from the tissues, and chemically maintaining an environment rich in calcium, phosphate and acid buffering agents (Anderson 2003).

More than 700 oral microbial species have now been identified, making oral flora one of themost complex microbial communities in the human body (Kedjarune et al., 1997; Aas., 2005). Saliva could act as an oralcirculating fluid for bacterial transmission and act as a reservoir for bacterial colonization (Paster et al., 2001).

Bacteria, including anaerobic species, can survive in saliva and utilize salivary constituents for growth (Greenstein et al., 1997; De Jong et al., 1984; Bowden., 1997).

Table.1 Analysis of Salivary pH before and after restoration and comparison between the three groups (I, II, III) byone-way ANOVA

\begin{tabular}{|c|c|c|c|c|c|c|c|c|c|c|c|c|}
\hline \multirow[t]{3}{*}{ Groups } & \multirow{2}{*}{\multicolumn{2}{|c|}{$\begin{array}{l}\text { Before } \\
\text { restoration }\end{array}$}} & \multirow{2}{*}{\multicolumn{2}{|c|}{15 days }} & \multirow{2}{*}{\multicolumn{2}{|c|}{30 days }} & \multicolumn{6}{|c|}{ Changes from before restoration to } \\
\hline & & & & & & & \multicolumn{3}{|c|}{15 days } & \multicolumn{3}{|c|}{30 days } \\
\hline & Mean & SD & Mean & SD & Mean & SD & Mean & SD & $\mathrm{P}$ value & Mean & SD & $\mathrm{P}$ value \\
\hline Group I & 6.00 & 0.94 & 7.50 & 0.85 & 7.90 & 0.74 & 1.50 & 0.97 & $0.0009 *$ & 1.90 & 1.20 & $0.0007 *$ \\
\hline Group II & 6.05 & 0.72 & 7.25 & 0.49 & 7.85 & 0.41 & 1.20 & 0.48 & $0.0001 *$ & 1.80 & 0.54 & $0.0001^{*}$ \\
\hline Group III & 6.40 & 0.66 & 7.25 & 0.35 & 7.65 & 0.78 & 0.85 & 0.58 & $0.0012 *$ & 1.25 & 0.89 & 0.0014 \\
\hline \multicolumn{13}{|c|}{ Pair wise comparisons by Tukeys multiple posthoc procedures } \\
\hline $\begin{array}{l}\text { Group I vs } \\
\text { Group II }\end{array}$ & \multicolumn{2}{|c|}{$\mathrm{p}=0.9890$} & \multicolumn{2}{|c|}{$\mathrm{p}=0.6263$} & \multicolumn{2}{|c|}{$\mathrm{p}=0.9846$} & \multicolumn{3}{|c|}{$\mathrm{p}=0.6176$} & \multicolumn{3}{|c|}{$\mathrm{p}=0.9678$} \\
\hline $\begin{array}{l}\text { Group I vs } \\
\text { Group III }\end{array}$ & \multicolumn{2}{|c|}{$\mathrm{p}=0.4986$} & \multicolumn{2}{|c|}{$\mathrm{p}=0.6263$} & \multicolumn{2}{|c|}{$\mathrm{p}=0.6818$} & \multicolumn{3}{|c|}{$\mathrm{p}=0.1207$} & \multicolumn{3}{|c|}{$\mathrm{p}=0.2681$} \\
\hline $\begin{array}{l}\text { Group II } \\
\text { vs Group } \\
\text { III }\end{array}$ & \multicolumn{2}{|c|}{$\mathrm{p}=0.5849$} & \multicolumn{2}{|c|}{$\mathrm{p}=0.9999$} & \multicolumn{2}{|c|}{$\mathrm{p}=0.7815$} & \multicolumn{3}{|c|}{$\mathrm{p}=0.5214$} & \multicolumn{3}{|c|}{$\mathrm{p}=0.3843$} \\
\hline
\end{tabular}

$* \mathrm{p}<0.05$, \# applied paired t test

Table.2 Analysis of Salivary buffer capacity before and after restoration and comparison between the three groups (I, II, III) by paired t test

\begin{tabular}{|c|c|c|c|c|c|c|c|c|c|c|c|c|}
\hline \multirow[t]{3}{*}{ Groups } & \multirow{2}{*}{\multicolumn{2}{|c|}{$\begin{array}{l}\text { Before } \\
\text { restoration }\end{array}$}} & \multirow{2}{*}{\multicolumn{2}{|c|}{15 days }} & \multirow{2}{*}{\multicolumn{2}{|c|}{30 days }} & \multicolumn{6}{|c|}{ Changes from before restoration to } \\
\hline & & & & & & & \multicolumn{3}{|c|}{15 days } & \multicolumn{3}{|c|}{30 days } \\
\hline & Mean & SD & Mean & SD & Mean & SD & Mean & SD & P value & Mean & SD & P value \\
\hline Group I & 1.30 & 0.63 & 2.15 & 0.88 & 2.50 & 0.67 & 0.85 & 0.47 & $0.0003 *$ & 1.20 & 0.48 & $0.0001 *$ \\
\hline Group II & 1.25 & 0.89 & 2.55 & 0.83 & 3.15 & 0.85 & 1.30 & 0.42 & $0.0001 *$ & 1.90 & 0.39 & $0.0001 *$ \\
\hline Group III & 1.40 & 0.66 & 2.55 & 0.64 & 3.30 & 0.48 & 1.15 & 0.47 & $0.0001^{*}$ & 1.90 & 0.77 & $0.0001 *$ \\
\hline \multicolumn{13}{|c|}{ Pair wise comparisons by Tukeys multiple posthoc procedures } \\
\hline $\begin{array}{l}\text { Group I vs } \\
\text { Group II }\end{array}$ & \multicolumn{2}{|c|}{$\mathrm{p}=0.9875$} & \multicolumn{2}{|c|}{$\mathrm{p}=0.5056$} & \multicolumn{2}{|c|}{$\mathrm{p}=0.1035$} & \multicolumn{3}{|c|}{$\mathrm{p}=0.0895$} & \multicolumn{3}{|c|}{$\mathrm{p}=0.0291 *$} \\
\hline $\begin{array}{l}\text { Group I vs } \\
\text { Group III }\end{array}$ & \multicolumn{2}{|c|}{$\mathrm{p}=0.9506$} & \multicolumn{2}{|c|}{$\mathrm{p}=0.5056$} & \multicolumn{2}{|c|}{$\mathrm{p}=0.0372 *$} & \multicolumn{3}{|c|}{$\mathrm{p}=0.3226$} & \multicolumn{3}{|c|}{$\mathrm{p}=0.0291 *$} \\
\hline $\begin{array}{l}\text { Group II vs } \\
\text { Group III }\end{array}$ & \multicolumn{2}{|c|}{$\mathrm{p}=0.8923$} & \multicolumn{2}{|c|}{$\mathrm{p}=0.9990$} & \multicolumn{2}{|c|}{$\mathrm{p}=0.8765$} & \multicolumn{3}{|c|}{$\mathrm{p}=0.7462$} & \multicolumn{3}{|c|}{$\mathrm{p}=0.9999$} \\
\hline
\end{tabular}

${ }^{*} \mathrm{p}<0.05, \#$ applied paired t test 
Table.3 Analysis of S.mutans count before and after restoration and comparison between the three groups (I, II, III) byone-way ANOVA

\begin{tabular}{|c|c|c|c|c|c|c|c|c|c|c|c|c|}
\hline \multirow[t]{3}{*}{ Groups } & \multirow{2}{*}{\multicolumn{2}{|c|}{$\begin{array}{l}\text { Before } \\
\text { restoration }\end{array}$}} & \multirow{2}{*}{\multicolumn{2}{|c|}{15 days }} & \multirow{2}{*}{\multicolumn{2}{|c|}{30 days }} & \multicolumn{6}{|c|}{ Changes from before restoration to } \\
\hline & & & & & & & \multicolumn{3}{|c|}{15 days } & \multicolumn{3}{|c|}{30 days } \\
\hline & Mean & SD & Mean & SD & Mean & SD & Mean & SD & $P$ value & Mean & SD & $\mathrm{P}$ value \\
\hline Group I & 5.40 & 1.75 & 3.10 & 1.30 & 1.98 & 1.03 & 2.30 & 0.74 & $0.0001 *$ & 3.42 & 0.77 & $0.0001 *$ \\
\hline Group II & 4.76 & 1.48 & 2.76 & 0.79 & 1.21 & 0.46 & 2.00 & 0.98 & $0.0001^{*}$ & 3.55 & 1.21 & $0.0001 *$ \\
\hline Group II & 5.50 & 1.16 & 2.94 & 0.52 & 1.57 & 0.44 & 2.56 & 0.69 & $0.0001 *$ & 3.93 & 0.93 & $0.0001^{*}$ \\
\hline \multicolumn{13}{|c|}{ Pair wise comparisons by Tukeys multiple posthoc procedures } \\
\hline $\begin{array}{l}\text { Group I vs } \\
\text { Group II }\end{array}$ & \multicolumn{2}{|c|}{$\mathrm{p}=0.6032$} & \multicolumn{2}{|c|}{$\mathrm{p}=0.6894$} & \multicolumn{2}{|c|}{$\mathrm{p}=0.0523$} & \multicolumn{3}{|c|}{$\mathrm{p}=0.6906$} & \multicolumn{3}{|c|}{$\mathrm{p}=0.9569$} \\
\hline $\begin{array}{l}\text { Group I vs } \\
\text { Group III }\end{array}$ & \multicolumn{2}{|c|}{$\mathrm{p}=0.9884$} & \multicolumn{2}{|c|}{$\mathrm{p}=0.9205$} & \multicolumn{2}{|c|}{$\mathrm{p}=0.4005$} & \multicolumn{3}{|c|}{$\mathrm{p}=0.7597$} & \multicolumn{3}{|c|}{$\mathrm{p}=0.4932$} \\
\hline $\begin{array}{l}\text { Group II } \\
\text { vs Group } \\
\text { III }\end{array}$ & \multicolumn{2}{|c|}{$\mathrm{p}=0.5142$} & \multicolumn{2}{|c|}{$\mathrm{p}=0.8996$} & \multicolumn{2}{|c|}{$\mathrm{p}=0.4947$} & \multicolumn{3}{|c|}{$\mathrm{p}=0.2906$} & \multicolumn{3}{|c|}{$\mathrm{p}=0.6662$} \\
\hline
\end{tabular}

*p $<0.05$, \# applied paired t test

Carious tooth surfaces may induce intraoral changes, such as increased plaque accumulation, elevated bacterial colonization, reduced carbohydrate clearance, and increased acid production and also contributes to constant reinfection of the patient's mouth by maintaining the microbiological risk of development of new lesions (Loesche, 1986). Aminabadi et al., (2013) observed that the increase in $\mathrm{pH}$ has a linear relationship with the number of eliminated carious tooth surfaces and concluded that saliva quality can be substantially improved by eliminating dental caries (Krasse., 1986). Windowati et al., (2013) observed patients with high caries risk have significantly lower salivary $\mathrm{pH}$ compared to patients with low caries risk.

Glass ionomer cements are capable of elevating the $\mathrm{pH}$ to the level which could arrest the caries (Windowati et al., 2013). GIC inhibits the $\mathrm{pH}$ fall due to slow but steady release of fluoride from GIC, especially at acidic conditions (Humphrey, 1950). Several studies support these findings (Windowati et al., 2013; Humphrey., 1950; Krishnamurthy., 2012; Topcuoglu et al., 2012).

In our study, we have also found significant improvement in the buffer capacity in the GIC group which can be attributed to the attack at the matrix releases both poly acrylic acid and metal ions. Consequently, the storage solution becomes a mixture of lactic acid and metal lactates, the classic combination that creates a buffer solution (Krishnamurthy, 2012).

Conventional composite shows no buffering ability. Buffering capacity directly influences the demineralization process of the adjacent tooth tissue, but it was also demonstrated that the inability of composite to increase the local $\mathrm{pH}$ facilitates the growth of aciduric and cariogenic bacteria (Willershausen et al., 2003). This is in contrast to the results of our study which can be attributed to the fact that, the smoother surface of composite restorations decreases the bacterial adhesion and thereby depleting the bacterial reservoir (Imazato, 2003).

Stainless steel crown (SSC) was introduced by Humphrey in 1950 (Seale, 2002). Since 1950, SSCs have been widely used for the restoration of grossly destructed carious primary teeth and those teeth requiring pulp therapy or where other restorative materials are likely to fail. The SSC is easy to place, economical and it has the excellent durability (Braff, 1975). Braff et al., (1975) stated that SSCswere significantly superior to multisurface amalgams in the restoration of primary molars. Willershausen (2003) showed a potential positive inhibitory effect of stainless steel crown restorations as compared to composite fillings with respect to the oral bacterial colonization (Nicholson, 1999). The present study shows a significant improvement in the salivary $\mathrm{pH}$ and buffer capacity and reduction in S.mutans count in the Stainless Steel crown group which may be due to lack bacterial adhesion sites leading to depletion of the bacterial reservoir.

The present study, compared saliva before and after eliminating carious lesions. There was a significant increase in salivary $\mathrm{pH}$ and buffering capacity, and a significant decrease in the S.mutans count at the end of the study in all the three groups. Studies have shown an inverse relation, between the salivary $\mathrm{pH}$ and buffer capacity and the number of bacteria present in the saliva (Kesel et al., 1958; Elliot et al., 1964; Ryu et al., 2010). 
Keene et al., (1976) and Loesch et al.,(1977) showed a reduction in the number of sites of S.mutans and also a decrease in the proportion of $\mathrm{S}$. mutans to total streptococci, thus making the oral environment more alkaline by increasing the salivary $\mathrm{pH}$ which was correlating with our results.

In conclusion, Removal of the caries itself improves the salivary properties like salivary $\mathrm{pH}$, buffer capacity and reduces the S.mutans count, irrespective of the materials used.

\section{References}

Aas JA, Paster BJ.2005. Defining the normal bacterial flora of the oral cavity. J ClinMicrobiol; 43(11):5721-5732.

Ai JY, Smith B, Wong DT.2012. Bioinformatics advances in saliva diagnostics. Int J Oral Sci; 4(2): 85-87.

Amerongen AVN, Bolscher JGM, Veerman ECI.2004. Salivary proteins: Protective and diagnostic value in cariology. Caries Res; 38: 247-253.

Aminabadi N, Najafpour E, Rohani Z, Delijavan A, Ghojazadeh M, Jamali Z. 2013. Linear reciprocal interaction between dental caries and slivary characteristics. J Oal Sci; 55(4):337-42

Anderson LA, Orchadson R.2003. The effect of chewing bicarbonate-containing gum on salivary flow rate and $\mathrm{pH}$ in humans. Arch Oral Biol; 48(3):201-4.

Bowden GH. 1997. Does assessment of microbial composition of plaque/saliva allow for diagnosis ofdisease activity of individuals? Community Dent Oral Epidemiol; 25(1):76-81.

Braff MH. 1975. A comparison between stainless steel crowns and multisurface amalgams in primary molars. ASDC JDent Child; 42:474- 8.

De Jong MH, van der Hoeven JS.1984. Growth of oral streptococcus species and Actinomycesviscosus in human saliva. Appl Environ Microbiol; 47(5):901-904.

Doyle, W.A. 1973. Prevention: how much, when, why, for whom. J Am SocPrev Dent 3:58

Elliot RP.1964. Full mouth rehabilitation etards oral lactobacilli. J Tenn Dental Assoc; 13:415-28

Greenstein G, Lamster IB.1997. Bacterial transmission in periodontal diseases: a critical review. JPeriodontol; 68(5):421-431.

Humphrey WP.1950. Uses of chrome steel in children's dentistry. Dent Surv; 26:945- 9.

I. Nedeljkovic J, De Munck V,Slomka B, Van Meerbeek W,Teughels, Van Landuyt KL. 2016. Lack of
Buffering by Composites Promotes Shift to More Cariogenic Bacteria. Journal of Dental Research, Vol. 95(8) 875-881

Imazato S. 2003. Antibacterial properties of resin composites and dentin bonding systems. Dental Materials; 19:449-457

Kedjarune U, Migasena P, Changbumrung S, Pongpaew $P$ and Tungtrongchitr R. 1997. Flow rate and Composition of whole saliva in children from rural and urban Thailand with different caries prevalence and Dietary intake. Caries Res; 31: 148-154.

Keene HJ, Shklair IL, Hoerman KC.1976. Partial elimination of streptococcus mutans from selected tooth surfaces after restoration of carious lesions and $\mathrm{SnF}_{2}$ prophylaxis. J Am Dent Assoc; 93:32833

Kesel HG, shklair IL, Green GH, Englander HR. 1958. Further studies onlactobacilli counts after elimination of carious lesions. J Dent Res; 37:50

Krasse B. 1986. Risco de carie - um guisprctico para availiaco e controle. Quintessence ed, Sao Paulo.

Krishnamurthy S.2012 April. The Effect of Capsulated Glass Ionomer Cements on the $\mathrm{pH}$ of a Lactic Acid Solution. Journal of Clinical and Diagnostic Research, Vol-6(2): 316-318

Loesch WJ, BradBury DR, Woolfolk MP.1977. Reduction of dental decay in rampant caries individuals following short term kanamycin treatment. J Dent Res; 56:254-65

Loesche WJ. 1986. Role of Streptococcus mutans in human dental decay. Microbiol Rev.; 50(4): 353380.

Malamud D, Isaac R. Rodriguez-Chavez.2011 January. Saliva as a Diagnostic Fluid. Dent Clin North Am; 55(1): 159-178

Massler, M. April 1969. Teen-age cariology. Dent Clin North Am 13: 405.

Mayanagi G, Igarashi K, Washio J, Nakajo K, DomonTawaraya H, Takahashi N. 2011. Evaluation of $\mathrm{pH}$ at the bacteria- dental cement interface. J Dent Res. 90(12):1446-1450.

Ng MW, Ramos-Gomez F, Lieberman M. 2014. Disease management of early childhood caries: ECC Collaborative Project. Int J Dent: 327801.

Ng MW, Ramos-Gomez F.2012. Disease prevention and management of early childhood caries. J Mass Dent Soc; 61(3): 28-32.

Nicholson JW, Czarnecka B, Limanowska-Shaw H.1999. A preliminary study of the effect of glass-ionomer and related dental cements on the $\mathrm{pH}$ of lactic acid storage solutions. Biomaterials; 20(2):155-158. 
Paster BJ, Boches SK.2001. Bacterial diversity in human subgingival plaque. J Bacteriol; 183(12):37703783.

Ryu M, Ueda T, Saito T, Yasui M, Ishihara K, Sakurai K. 2010. Oral environmental factors affecting number of microbes in saliva of complete denture weares. J Oral rehabil; 37:194-201

Schipper RG, Silletti E, Vingerhoeds MH. 2007. Saliva as research material: biochemical, physicochemical and practical aspects. Arch Oral Biol; 52(12): 1114-1135.

Seale NS. 2002. The use of stainless steel crowns. Pediatr Dent; 24:501-505.

Smith GA, Riedford K. 2013. Epidemiology of early childhood caries: clinical application. J PediatrNurs; 28(4): 369-373.

Sonbul, H, 2010. On Caries Risk Profile and Prevention in an Adult Saudi Population. University of Gothenburg, Goteborg, Sweden. Accessed 12 June 2013.

https://gupea.ub.gu.se/bitstream/2077/21947/2/gup ea_2077_21947_2.pdf.

How to cite this article:

Sunil Raj N., E. Umadevi and Sapna Konde. 2017. Salivary Indicators for a Healthy Mouth: An In Vivo Study. Int.J.Curr.Res.Aca.Rev. 5(7), 115-120. doi: https://doi.org/10.20546/ijcrar.2017.507.15
Stookey GK.2008 May. The effect of saliva on dental caries. JADA; 139.

Subramanyam D, Gurunathan D. 2016.Microbial evaluation of plaque on 3M ESPE and kids stainless steel crown in primary molars. Int $\mathbf{J}$ PedodRehabil; 1:60-3.

Topcuoglu N, Ozan F, Ozyurt M, Kulekci G.2012.In vitro antibacterial effects of glass ionomer cement containing ethanolic extract of propolis on Streptococcus mutans. Eur J Dent; 6:428-433

Willershausen B, Ernst CP, Kasaj A, Topf J, Pistorius A.2003. Influence of dental restorative materials on salivary Streptococcus mutans and lactobacilli in the primary dentition.Oral Health Prev Dent.; 1(2):157-62.

Windowati W, Akbar SH, Tin MH. 2013. Saliva pH changes in patients with high and low caries risk after consuming organic (sucrose) and non-organic (malitol) sugar. Int Med J Malaysia; 12(2):15-21.

Winter, G.B. 1973. Clinical procedures in the prevention of dental carles. Int Dent J Sept; 23:373. 